\begin{tabular}{c} 
Tersedia online di: http://ejournal-balitbang.kkp.go.id/index.php/bawal \\
e-mail:bawal.puslitbangkan@ gmail.com \\
BAWAL WIDYA RISET PERIKANAN TANGKAP \\
Volume 10 Nomor 2 Agustus 2018 \\
p-ISSN: 1907-8226 \\
e-ISSN: 2502-6410 \\
BAWAL \\
Nomor Akreditasi Kementerian RISTEKDIKTI: 21/E/KPT/2018 \\
\hline \hline
\end{tabular}

\title{
REPRODUKSI DAN MUSIM PEMIJAHAN TONGKOL KOMO (Euthynnus affinis) BERDASARKAN MONSUN DAN SUHU PERMUKAAN LAUT DI SAMUDERA HINDIA SELATAN JAWA-NUSA TENGGARA
}

\section{REPRODUCTION AND SPAWNING SEASON OF KAWAKAWA (Euthynnus affinis) BASED ON MONSOON AND SST DISTRIBUTION IN INDIAN OCEAN SOUTH OFF JAVA-NUSA TENGGARA}

\author{
Khairul Amri*1, Fajar Alfina Nora1, Dwi Ernaningsih² dan Thomas Hidayat 1 \\ ${ }^{1}$ Balai Penelitian Perikanan Laut, Kompleks Raiser Ikan Hias Cibinong - Bogor, Indonesia \\ ${ }^{2}$ Fakultas Perikanan dan Ilmu Kelautan USNI, J1. Sultan Iskandar Muda 11, Jakarta, Indonesia \\ Teregistrasi I tanggal: 20 November 2017; Diterima setelah perbaikan tanggal: 28 Agustus 2018; \\ Disetujui terbit tanggal: 05 Desember 2018
}

\begin{abstract}
ABSTRAK
Samudera Hindia di sebelah Selatan Jawa merupakan salah satu habitat penting bagi ikan pelagis jenis tongkol komo (Euthynnus affinis). Keberadaan stok ikan di perairan ini sangat dipengaruhi oleh proses oseanografi yang berlangsung di daerah tersebut. Penelitian ini bertujuan mengkaji aspek reproduksi dan dugaan musim pemijahan tongkol komo di selatan Jawa berdasarkan monsun dan suhu permukaan laut (SPL). Sebanyak 152 ekor contoh ikan dan gonad diperoleh dari 3 lokasi pendaratan ikan yaitu Palabuhanratu, Sendang Biru dan Tanjung Luar pada tahun 2013. Analisa sampel gonad dilakukan tahun 2014 di Laboratorium Biologi, Balai Riset Perikanan Laut. Data Suhu Permukaan Laut (SPL) diunduh dari Citra Satelit Aqua MODIS level-3, situs resmi NASA tahun 2012-2013. Hubungan antar parameter dianalisis secara deskriptif. Hasil penelitian menunjukkan musim pemijahan berlangsung antara Mei-Oktober bersamaan dengan musim timur sampai dengan musim peralihan II, dimana durasi di perairan selatan Jawa lebih panjang dibandingkan dengan perairan lainnya. Fase matang gonad (Tingkat Kematangan Gonad IV) betina sebanyak 55\% dan gonad jantan sebanyak 40\% diperoleh pada bulan Juli. Berikutnya, pada bulan Oktober sekitar $11 \%$ sampel gonad ikan betina sudah memijah (spent). Fekunditas tertinggi dan diameter telur terbesar sebagai indikator pemijahan, ditemukan pada musim timur dan musim peralihan II, bersamaan dengan terjadinya upwelling di perairan selatan Jawa yang ditandai dengan nilai sebaran suhu permukaan laut (SPL) rendah. Terdapat kesamaan waktu antara puncak musim pemijahan dengan puncak musim penangkapan ikan tongkol komo di perairan selatan Jawa.
\end{abstract}

Kata Kunci: Reproduksi; pemijahan; tongkol komo; SPL; selatan Jawa-Nusa Tenggara

\section{ABTRACT}

Indian Ocean South off Java-Nusa Tenggara as an important habitat of pelagic fish, kawa-kawa (Euthynnus affinis). The fish stocks in those areas affected by oceanographical prosessed. This study aimed to analyze the reproduction aspects and spawning prediction of kawakawa and its relation with monsoon and sea surface temperature (SST) conditions. Gonad samples were obtained from 3 fish landing sites at Palabuhanratu, Sendang Biru and Tanjung Luar in 2013. Analysis of 152 fishes and gonad samples were conducted in 2014 at Biology Laboratory of Research Institute for Marine Fisheries. SST data was taken from Aqua MODIS satellite imagery level 3 (2012-2013), downloaded from the NASA website. The analysis is done descriptively. The results showed that spawning season of kawakawa occurs in May-October (east monsoon to transitional monsoon II), its duration was longer than in other waters. Based on the gonad maturity stages, gonad mature (stage IV) found to be dominant in July (east monsoon), which is 55\% female and $40 \%$ of male gonad samples. Based on the GSI value, spawning peak season occurred in September (transitional monsoon II) and a month later (October) about $11 \%$ of female fish gonad samples showed an indication of spawning (spent). The highest fecundity with the largest egg dimater range as spawning indicator was found in east monsoon to transitional monsoon II. Spawning season of kawakawa occurs along with upwelling events in these waters, with lowest SST. The peak of the spawning season and the fishing season was happened in the same time.

Keywords: Reproduction; spawning; kawakawa, monsoons, SPL; South Java-Nusa Tenggara waters 


\section{PENDAHULUAN}

Perairan Samudera Hindia di Selatan Jawa-Nusa Tenggara merupakan habitat penting sumber daya tongkol komo (Euthynnus affinis) atau kawakawa. Ikan jenis ini dimasukan dalam kelompok neritic tuna yaitu jenis ikan tuna yang hidup di perairan pantai (coastal). Pengelolaan sumberdaya ikan tuna neritik di perairan selatan Jawa di bawah manajemen IOTC/India Ocean Tuna Comission (Herrera \& Pierre, 2009). Dari kelompok jenis tuna neritik tersebut, prosentase produksi tongkol komo di Samudera Hindia cukup dominan yaitu mencapai $27 \%$, sisanya berupa tongkol krai dan lisong (25\%); tongkol abu-abu (24\%), tenggiri batang $18 \%$ dan tenggiri papan sekitar $6 \%$ (FAO, 2013).

IOTC (2006) menyebutkan bahwa sumber daya tongkol komo di perairan Samudera Hindia adalah merupakan satu unit stok. Hidupnya berasosiasi dengan jenis tuna lainnya seperti yuwana madidihang, cakalang, tongkol lisong dan tongkol krai. Mereka membentuk ' $f i s h$ schoaling' serta merupakan ikan piscivorous yaitu pemakan jenis ikan lainnya (Chiou et al., 2004).

Nelayan perairan selatan Jawa-Nusa Tenggara sudah sejak lama memanfaatkan tongkol komo. Ikan jenis ini pada saat musim penangkapan banyak didaratkan di Palabuhanratu (Jawa Barat), Cilacap (Jawa Tengah), Prigi (Jawa Timur) dan Tanjung Luar (Lombok Timur). Nelayan menangkap tongkol komo sebagai tangkapan utama menggunakan jaring payang dan sebagian lagi dengan bagan, gill net serta purse seine (Amri et al., 2013-a).

Ikan tongkol komo merupakan jenis ikan pelagis yang hidup di perairan neritik dengan kedalaman <200 m (Herrera \& Pierre, 2009). Ikan ini umumnya ditemukan di perairan dekat pulau dan banyak ditemukan di perairan sekitar pulau-pulau oseanik bersuhu hangat (Collette \& Nauen, 1983). Keberadaan sumber daya ikan pelagis sangat tergantung pada faktor-faktor lingkungan (kondisi oseanografi dan ketersediaan makanan) sehingga kelimpahan sangat berfluktuasi di suatu perairan. Perubahan suhu perairan yang sangat kecil $\left(0,02^{\circ} \mathrm{C}\right)$ dapat menyebabkan perubahan densitas populasi ikan di perairan tersebut (Laevastu \& Hayes, 1980).

Stok ikan pelagis juga sangat peka terhadap perubahan penyebaran spasial suhu dan salinitas yang dibangkitkan oleh angin muson timur/tenggara (Potier, 1988). Proses upwelling di perairan selatan Jawa terjadi pada musim timur (Wyrtki (1962), disebabkan oleh angin muson tenggara. Nontji (1987) mengungkapkan bahwa upwelling di selatan Jawa dibangkitkan oleh arus khatulistiwa selatan (AKS) dan juga angin muson tenggara dan terjadi sekitar bulan Mei hingga September. Pada musim timur (bulan Juni hingga Oktober) intensitas upwelling mengalami peningkatan sehingga menyebabkan SPL lebih dingin dan serta klorofil-a lebih tinggi dibandingkan pada musim barat (Kunarso et al., 2012). Nybakken (1992) menyebutkan pada perairan dengan kandungan zat hara tinggi, seperti di daerah upwelling, produksi plankton hampir selalu melimpah dan diikuti dengan produksi ikan yang cukup tinggi (Nybakken, 1992).

Meskipun sumber daya tongkol komo memiliki nilai ekonomis penting, hasil penelitian tentang biologi reproduksi ikan ini masih terbatas (Motlagh et al., 2010). Selanjutnya Hidayat et al. (2016) menyatakan penelitian terkait reproduksi tongkol komo selama ini terkonsentrasi di perairan Samudera Pasifik bagian barat, sementara untuk perairan Samudera Hindia informasinya masih sedikit. Beberapa penelitian biologi reproduksi tongkol komo antara lain dilaporkan oleh Rao (1964) dan Muthiah (1985) yang mengkaji fekunditas ikan ini di perairan India. Klinmuang (1978) mengkaji fekunditas tongkol komo di perairan Laut Cina Selatan; Ardelia et al. (2016) di perairan Selat Sunda; sementara Hidayat et al.(2016) meneliti pola dan musim pemijahannya di Laut Jawa.

Aspek biologi reproduksi yang penting untuk diamati antara lain fekunditas dan diamater telur, yang sangat terkait dengan dugaan waktu dan lokasi pemijahan. Ali (2005) menyatakan bahwa fekunditas suatu spesies ikan cenderung meningkat dengan bertambahnya ukuran badan yang dipengaruhi oleh jumlah makanan dan faktorfaktor lingkungan lainnya seperti musim dan suhu perairan. Abdussamad et al. (2012) melaporkan musim pemijahan tongkol komo di perairan Samudera Hindia bagian barat (perairan India) umumnya berlangsung dua kali yaitu MeiJuni dan Oktober-Desember.

Penelitian ini bertujuan mengkaji aspek reproduksi dan dugaan musim pemijahan tongkol komo di perairan Samudera Hindia selatan Jawa berdasarkan musim (muson) dan kondisi suhu perairan. Diharapkan, informasinya berguna dalam pengelolaan sumber daya, terutama untuk memprediksi pola dan waktu rekruitmen.

\section{METODEPENELITIAN Pengumpulan Data}

Aspek reproduksi ikan tongkol komo yang diamati adalah jenis kelamin, tingkat kematangan gonad (TKG), indeks kematangan gonad (IKG), fekunditas dan diameter telur. Sampel gonad jantan dan betina dikumpulkan pada tahun 2013 dari tiga lokasi pendaratan utama di selatan Jawa dan Lombok, yaitu di Pelabuhan Perikanan Nusantara (PPN) Palabuhanratu (Jawa Barat); Tempat Pelelangan Ikan (TPI) Sendang Biru (Jawa Timur); dan TPI Tanjung Luar (Lombok) (Gambar 1). Sampel gonad diamati dari 152 ekor ikan dewasa (jantan dan betina). Estimasi fekunditas dilakukan dengan mengambil spesimen telur (gonad ikan betina) yang matang (TKG III dan IV) dari 60 ekor ikan betina. 
Data kondisi lingkungan perairan (suhu permukaan laut/SPL) berasal dari citra satelit Aqua MODIS (Moderate
Resolution Imaging Spectroradiometer) level3 (2012-2013) yang diunduh dari situs resmi NASA (http://gdata1.sci.gsfc.nasa.gov).

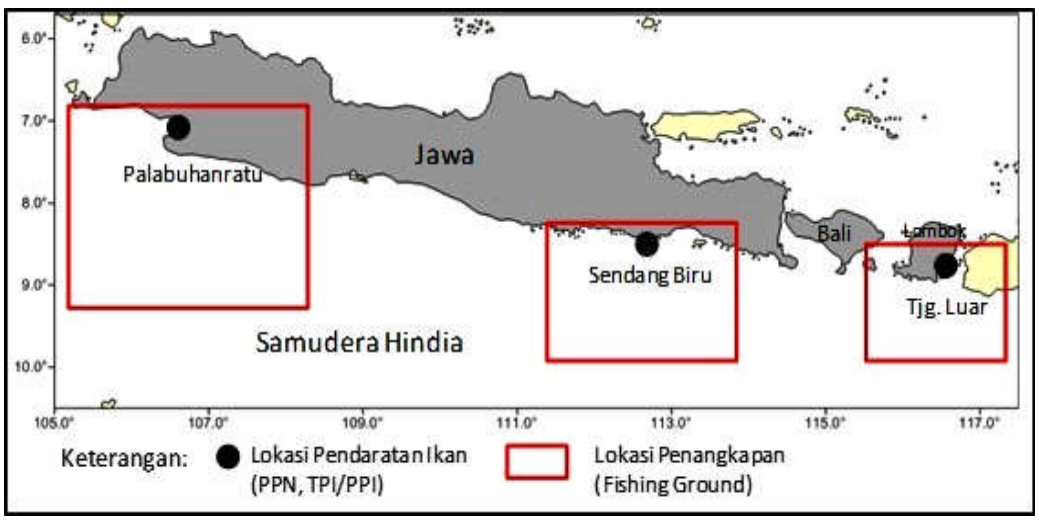

Gambar 1. Lokasi pengambilan sampel ikan tongkol komo di selatan Jawa dan Nusa Tenggara.

Figure 1. Map showing sampling area for kawakawa in the south off Java-Nusa Tenggara waters.

\section{Analisis Gonad}

Pengamatan dan analisa sampel gonad dilakukan di Lab. Biologi Balai Riset Perikanan Laut (BRPL). Penentuan TKG mengacu pada Holden \& Raitt (1974) yang terdiri atas lima tingkatan. Indeks Kematangan Gonad (IKG) atau Gonado Somatic Index (GSI) dihitung dari persentase perbandingan berat gonad dan berat ikan. Nilai IKG semakin lama semakin besar sampai batas kisaran maksimum, kemudian akan terjadi penurunan (memijah), sehingga dapat diduga musim pemijahannya. Indeks IKG dianalisis berdasarkan Effendie (2002) :

$\mathrm{IKG}=(\mathrm{Bg} / \mathrm{Bt}) \times 100 \%$

dimana;

IKG: Indeks Kematangan Gonad

$\mathrm{Bg}$ : berat gonad (gram)

Bt : berat tubuh ikan - berat gonad (gram)

Fekunditas ikan ditentukan menggunakan metode gravimetrik (Effendie, 1979):

$F=\left(\frac{G}{Q}\right) x N$

dimana;

$\mathrm{F}=$ fekunditas (butir)

$\mathrm{G}=$ berat $\operatorname{gonad}(\mathrm{gr})$

$\mathrm{Q}=$ berat gonad contoh (gr)

$\mathrm{N}=$ jumlah telur tiap gonad contoh (butir)

Pola sebaran diameter telur dianalisis secara deskriptif dengan melihat modus penyebaran ukuran. Apabila terlihat dua modus penyebaran, maka pola pemijahannya bersifat partial spawning (sebagian demi sebagian) dan jika satu modus berarti total spawning (berlangsung dalam waktu singkat) (Effendie,1997).

\section{Analisis Musim Penangkapan}

Dugaan musim penangkapan diketahui dari indeks musim penangkapan (IMP), dengan menganalisa data produksi perikanan di PPN Palabuhanratu pada 2009-2013. IMP ditentukan menggunakan metode persentase ratarata (the average percentage methods) produksi, yang didasarkan pada analisis runtun waktu (times series analysis) (Spiegel, 1961) sebagai berikut:

1. Menghitung rata-rata bulanan

$$
\overline{x i}=\frac{\sum x i j}{n}
$$

2. Menghitung rata-rata umum

$$
\bar{\mu}=\frac{\sum_{i=1}^{12} i_{j=i}^{\sum^{n}}}{n}
$$

3. Indeks musim

$$
I M=\frac{\overline{x i}}{\mu}-1
$$

Dimana;

$x i=$ rata-rata produksi bulanan untuk tahun tertentu

$\mu=$ rata-rata produksi bulanan untuk keseluruhan tahun

$\mathrm{IM}=$ indeks musim penangkapan ikan

$\mathrm{N}=$ jumlah tahun

$\mathrm{X} i j=$ hasil tangkapan pada bulan ke-j tahun ke-i

\section{Analisa SPL}

Data SPL dari sensor Aqua MODIS diolah dengan menggunakan software surfer 10 dan Ms. Excel. Dilakukan pemotongan citra (cropping) sesuai wilayah penelitian. Hasil pemotongan citra tersebut berupa data ASCII yang terdiri dari variabel bujur, lintang. Nilai estimasi SPL kemudian diolah lebih lanjut untuk membuat sebaran spasial. 
Analisa Hubungan Fekunditas dengan Musim dan SPL

Analisa hubungan antara pemijahan berdasarkan musim dan SPL, dilakukan secara deskriptif. Analisa nilai dan pola sebaran SPL dilakukan secara digital dan visual. Selanjutnya TKG, GSI serta fekunditas dan diameter telur dikaitkan dengan dinamika nilai dan sebaran suhu permukaan laut untuk menduga pemijahan berdasarkan kerangka musim (monsun) yang berlangsung di selatan Jawa.

\section{HASIL DAN BAHASAN}

Hasil

\section{Perkembangan Gonad}

Perkembangan gonad yang dilihat dari TKG-nya menunjukkan TKG I sampai IV ditemukan hampir setiap bulan. Namun, fase matang gonad (TKG IV) hanya ditemukan pada bulan Februari, Juli dan Oktober (ikan jantan) serta Juli dan Oktober (ikan betina). Fase selesai memijah/spent (TKG V) ditemukan pada Juli (ikan jantan) dan pada Oktober (ikan betina) (Tabel 1).

Pada bulan Juli, sebanyak 55\% ikan betina sudah matang gonad (TKG IV) dan $18 \%$ TKG III. Sementara ikan jantan, sekitar 7\% sudah memijah (spent) dan $40 \%$ matang gonad (TKG IV) serta 47\% TKG III. Pada bulan Oktober, sekitar $11 \%$ ikan betina fase spent; $33 \%$ matang gonad (TKG IV); dan 22\% TKG III. Sementara untuk ikan jantan yang matang gonad (TKG IV) sekitar 14\% dan $29 \%$ TKG III. Pada Februari juga ditemukan sekitar $20 \%$ ikan jantan sudah matang gonad (TKG IV).

Nilai indeks kematangan gonad menunjukkan, IKG tertinggi ikan betina terjadi pada Februari dan Juli, selanjutnya menurun tajam pada Mei dan September (Gambar 3). Tingginya nilai IKG pada bulan Februari dan Juli terkait berat gonad yang mencapai maksimum sesaat sebelum ikan memijah, kemudian menurun dengan cepat selama pemijahan berlangsung hingga selesai (Mei dan September).

Tabel 1. TKG tongkol komo di perairan Selatan Jawa 2013

Table 1. Gonad Maturity Stage of kawakawa in Indian Ocean south of Java waters in 2013

\begin{tabular}{|c|c|c|c|c|c|c|c|c|c|c|c|c|c|}
\hline \multirow{3}{*}{ Bulan/Month } & \multicolumn{10}{|c|}{ TKG/Gonad Maturity Stage } & \multicolumn{2}{|c|}{$\begin{array}{c}\text { Jumlah/Amount } \\
\text { (ekor/ind.) }\end{array}$} & \multirow[t]{3}{*}{$\begin{array}{c}\text { Rasio/Ratio } \\
\mathrm{J} / M: \mathrm{B} / F\end{array}$} \\
\hline & \multicolumn{5}{|c|}{$\begin{array}{c}\text { Jantan/Male } \\
\text { (ekor/ind.) }\end{array}$} & \multicolumn{5}{|c|}{$\begin{array}{l}\text { Betina/Female } \\
\text { (ekor/ind.) }\end{array}$} & \multirow[t]{2}{*}{$\begin{array}{l}\text { Jantan/ } \\
\text { Male }\end{array}$} & \multirow[t]{2}{*}{$\begin{array}{l}\text { Betina/ } \\
\text { Female }\end{array}$} & \\
\hline & I & II & III & IV & $\mathbf{V}$ & I & II & III & IV & $\mathbf{V}$ & & & \\
\hline Januari/January & 8 & 3 & - & - & - & 1 & 3 & - & - & - & 11 & 4 & $2,8: 1$ \\
\hline Februari/February & 1 & 3 & - & 1 & - & 1 & 8 & 3 & - & - & 5 & 12 & $1: 02,4$ \\
\hline Maret/March & 24 & 3 & 4 & - & - & - & - & 3 & - & - & 31 & 3 & $10,3: 1$ \\
\hline Mei/May & 1 & - & - & - & - & 10 & - & - & - & - & 1 & 10 & $1: 10$ \\
\hline Juli/July & 2 & - & 14 & 12 & 2 & - & 6 & 4 & 12 & - & 30 & 22 & $1,4: 1$ \\
\hline Oktober/October & 3 & 5 & 4 & 2 & - & 2 & 1 & 2 & 3 & 1 & 14 & 9 & $1,6: 1$ \\
\hline \multicolumn{11}{|c|}{ Total/Total } & 92 & 60 & \\
\hline
\end{tabular}

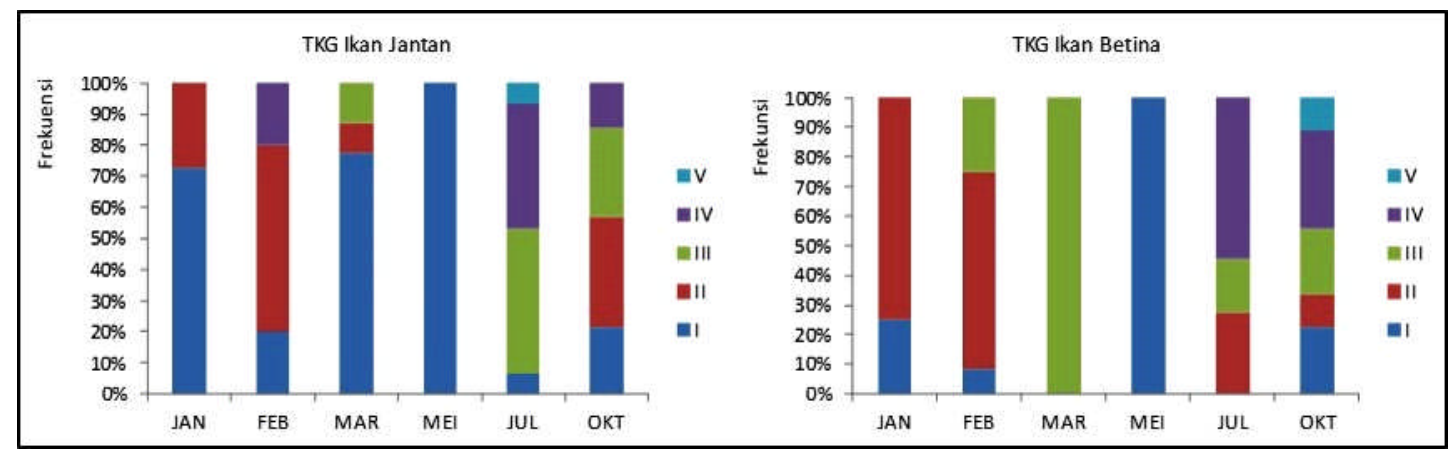

Gambar 2. Prosentase perkembangan TKG tongkol komo di perairan selatan Jawa-Nusa Tenggara 2013.

Figure 2. Percentage of Gonad Maturity Stage of kawakawa in Indian Ocean south off Java - Nusa Tenggara waters in 2013. 


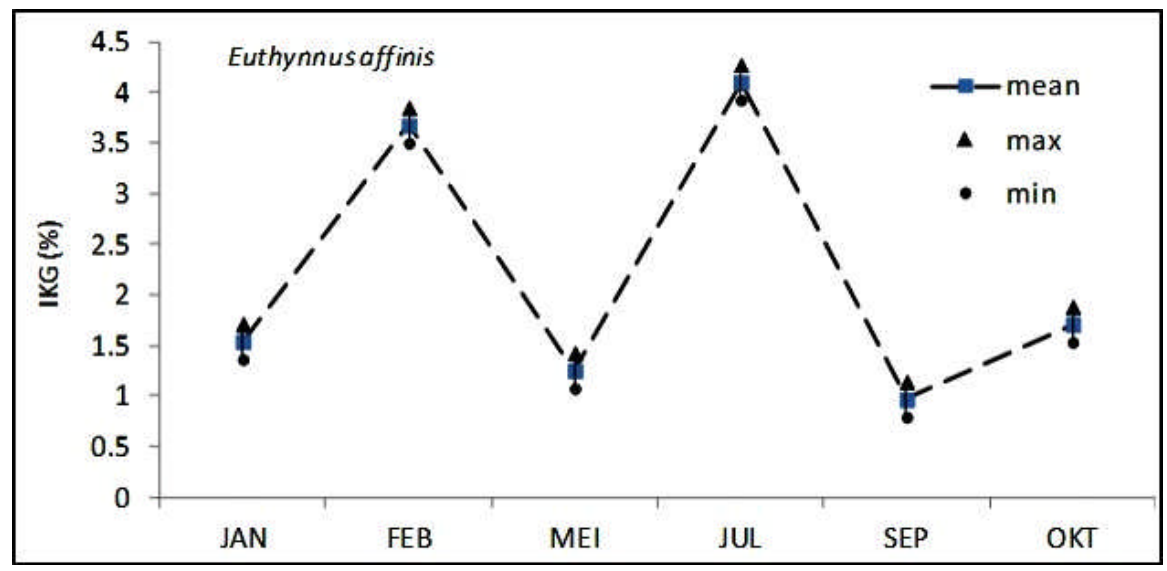

Gambar 3. Indeks kematangan gonad (IKG) tongkol komo di perairan selatan Jawa-Nusa Tenggara pada 2013.

Figure 3. Gonad Somatic Index/GSI of kawakawa in Indian Ocean south off Java-Nusa Tenggara waters in 2013.

\section{Fekunditas}

Fekunditas telur ikan betina berkisar antara 28.1672.389.667 butir (rata-rata antara 45.608-652.628 butir) dengan kisaran bobot tubuh antara 1.093-3.728 gr dan kisaran panjang cagak 40-63 cmFL (Tabel 2). Sampel ikan betina pada Mei dan Oktober (musim peralihan I dan II) di
Tanjung Luar dan Sendang Biru memiliki bobot lebih besar dibandingkan musim lainnya. Fekunditas terendah (sebanyak 219.167 butir) berasal dari sampel ikan yang ditangkap di perairan Tanjung Luar pada saat Musim Peralihan-I./MP-I Sementara fekunditas tertinggi berasal dari sampel ikan yang ditangkap di perairan Tanjung Luar pada MusimPeralihan-II/MP-II (sebanyak 711.994 butir) (Gambar4).

Tabel 2. Ukuran tubuh dan fekunditas tongkol komo di perairan selatan Jawa- Nusa Tenggara berdasarkan monsun 2013

Table 2. $\quad$ Size and fecundity of kawakawa based on monsoons in Indian Ocean south off Java - Nusa tenggara waters in 2013

\begin{tabular}{|c|c|c|c|c|c|}
\hline \multirow[b]{2}{*}{ Lokasi/Location } & \multirow[b]{2}{*}{$\begin{array}{c}\text { Bulan \& } \\
\text { Musim/Month \& } \\
\text { monsoon }\end{array}$} & \multicolumn{2}{|c|}{ Ukuran Ikan/Size of fish } & \multicolumn{2}{|c|}{ Fekunditas (btr)/Fecundity } \\
\hline & & $\begin{array}{c}\text { Panjang } \\
\text { cagak/Fork } \\
\text { length } \\
(\mathrm{cmFL}) \\
\end{array}$ & $\begin{array}{c}\text { Bobot/Weight } \\
\text { (gr) }\end{array}$ & Kisaran/Range & $\begin{array}{l}\text { Rerata/ } \\
\text { Average }\end{array}$ \\
\hline Palabuhanratu & $\begin{array}{l}\text { Juli/July } \\
\text { (MT/East } \\
\text { monsoon) } \\
\text { Oktober/October } \\
\text { (MP II/Inter } \\
\text { monsoon } \mathrm{II} \text { ) }\end{array}$ & $41-45$ & $1.223-2.190$ & $175.200-833.067$ & 652.628 \\
\hline Sendang Biru & Mei/May (MP I/ & & & & \\
\hline & Inter monsoon I) & $51-63$ & $1.975-3.728$ & $28.167-2.183 .467$ & 45.608 \\
\hline Tanjung Luar & $\begin{array}{l}\text { Mei/May (MP I/ } \\
\text { Inter monsoon I) } \\
\text { Oktober/October }\end{array}$ & $53-56$ & $2.013-2.178$ & $185.330-253.020$ & 219.167 \\
\hline & (MP II) & $40-59$ & $1.093-3.867$ & $110.833-2.389 .667$ & 711.994 \\
\hline
\end{tabular}




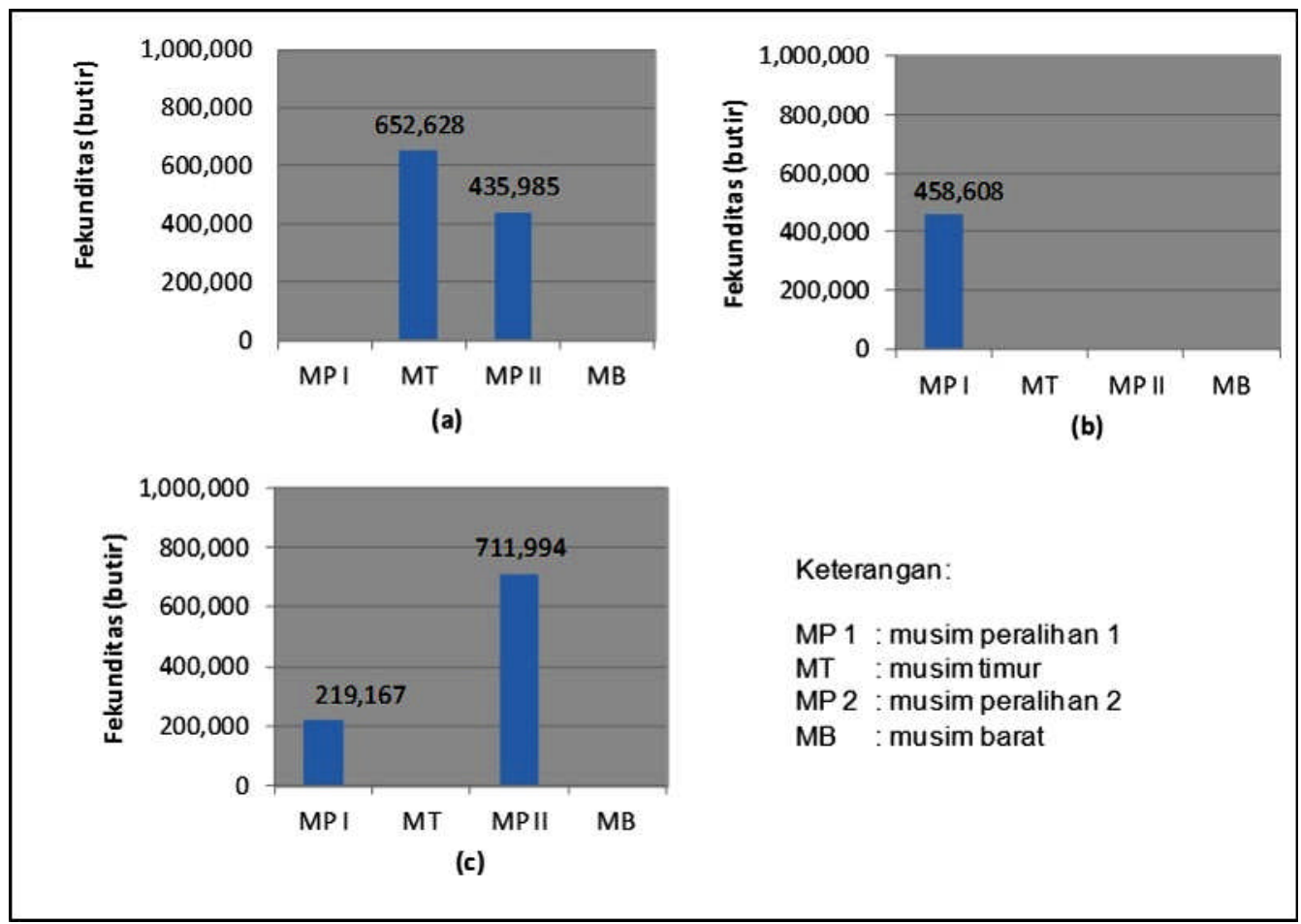

Gambar 4. Fekunditas rata-rata tongkol komo berdasarkan musim di lokasi (a) Palabuhanratu; (b) Sendang Biru; dan (c) Tanjung Luar 2013.

Fugure 4. Average of fecundity of kawakawa based of monsoons in (a) Palabuhanratu; (b) Sendang Biru; and (c) Tanjung Luar in 2013.

\section{Diameter Telur}

Kisaran diameter telur matang gonad (TKG III dan IV) bervariasi berdasarkan musim dan lokasi sampling (Tabel 3 dan Lampiran 1). Diameter telur di Palabuhanratu pada
MT dan MP II memiliki kisaran yang sama $(0,08-0,77 \mathrm{~mm})$ demikian juga di Sendang Biru pada MP I (0,08-0,77 mm); di Tanjung Luar, diameternya lebih besar berkisar antara 0,18-0,97 mm (MP I) dan antara 0,28-0,97 mm (MP II).

Tabel 3. Diameter telur tongkol komo berdasarkan musim di selatan Jawa 2013

Table 3. Egg diameter of kawakawa based on monsoons in Indian Ocean south off Java-Nusa Tenggara waters in 2013

\begin{tabular}{lcccc}
\hline \multirow{2}{*}{ Lokasi/Location } & \multicolumn{4}{c}{ Musim (Diameter telur: mm)/Monsoon (eggs dia.; mm) } \\
\cline { 2 - 5 } & $\begin{array}{l}\text { MP I/Inter } \\
\text { monsoon I }\end{array}$ & $\begin{array}{l}\text { MT/East } \\
\text { monsoon }\end{array}$ & $\begin{array}{l}\text { MP II/Inter } \\
\text { monsoon II }\end{array}$ & MB/West monsoon \\
\hline Palabuhanratu & N/A & $0,08-0,77$ & $0,08-0,77$ & N/A \\
Sendang Biru & $0,08-0,77$ & N/A & N/A & N/A \\
Tanjung Luar & $0,18-0,97$ & N/A & $0,28-0,97$ & N/A \\
\hline
\end{tabular}

Catatan/Remarks: $\quad$ MP I (Musim Peralihan I); MT (Musim Timur)

MP II (Musim Peralihan II); MB (Musim Barat)

Diameter telur dengan frekuensi tertinggi di Palabuhanratu (pada MT dan MP II) terdapat pada selang kelas 0,48-0,57 mm, sementara frekuensi terendah pada selang kelas 0,68-0,77 mm. Untuk perairan Sendang Biru (MP I), diameter telur dengan frekuensi tertinggi pada selang kelas 0,28-0,37 mm, sedangkan frekuensi terendah pada selang kelas $0,08-0,17 \mathrm{~mm}$. Untuk perairan Tanjung
Luar, pada MP I, diamater telur dengan frekuensi tertinggi pada selang kelas $0,38-0,47 \mathrm{~mm}$ dan frekeunsi terendah pada selang kelas 0,68-0,77 mm; sementara pada MP II diamater telur dengan frekuensi tertinggi pada selang kelas 0,38-0,47 $\mathrm{mm}$ dan frekeunsi terendah pada selang kelas 0,18-0,27 mm(Gambar 5). 


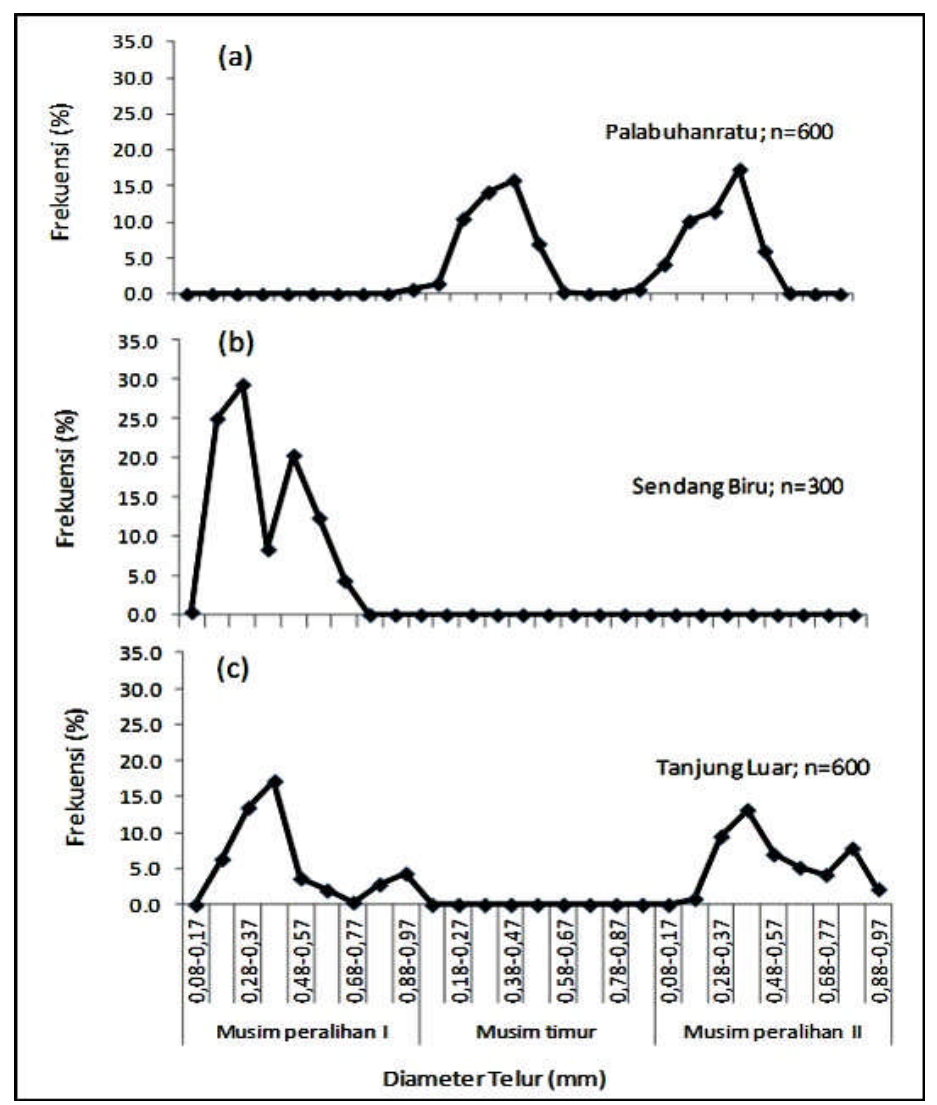

Gambar 5. Sebaran diameter telur tongkol komo di (a) Palabuhanratu; (b) Sendang Biru; dan (c) Tanjung Luar 2013. Figure 5. Distribution of egg diameter of kawakawa in (a) Palabuhanratu; (b) Sendang Biru; and (c) Tanjung Luar in 2013.

Dilihat dari distribusi diameter telur yang beragam (mulai telur yang berdiameter kecil hingga telur berdiameter besar) serta terdapat dua modus (heterogen), menandakan bahwa tongkol komo di perairan selatan Jawa memijah tidak sekaligus, tetapi tergolong partial spawner.

\section{Pola dan Nilai Sebaran SPL}

Citra satelit MODIS 2013 menunjukkan massa air di selatan Jawa memiliki SPL yang lebih hangat (warna merah) pada musim barat (MB) dan musim peralihan/MP I,

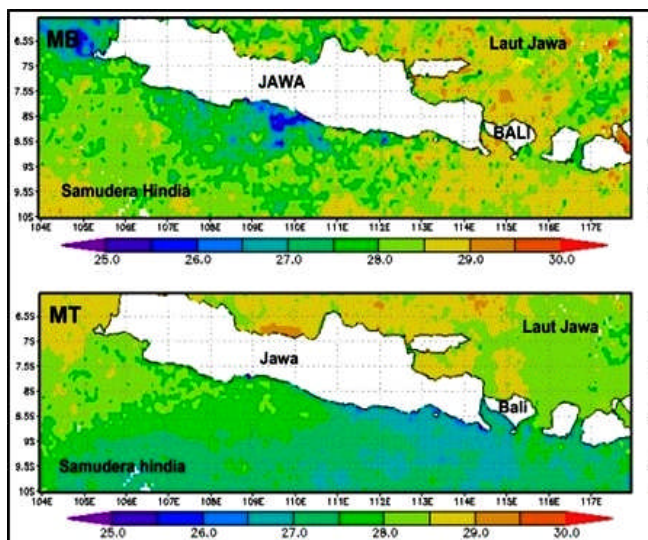

sementara pada musim timur (MT) dan musim peralihan/MP II cenderung lebih dingin (warna biru) (Gambar 6).

Secara umum, pola pergerakan SPL rata-rata bulanan pada tiap lokasi pengamatan (Palabuhanratu, Sendang Biru dan Tanjung Luar) cenderung meningkat pada Februari-Mei (MB dan MP I) dan menurun pada JuliOktober (MT dan MP II). Jika dibandingkan, nilai sebaran SPL pada MT (Juli-Agustus-September) pada 2012 jauh lebih rendah daripada 2013 (Gambar 7).

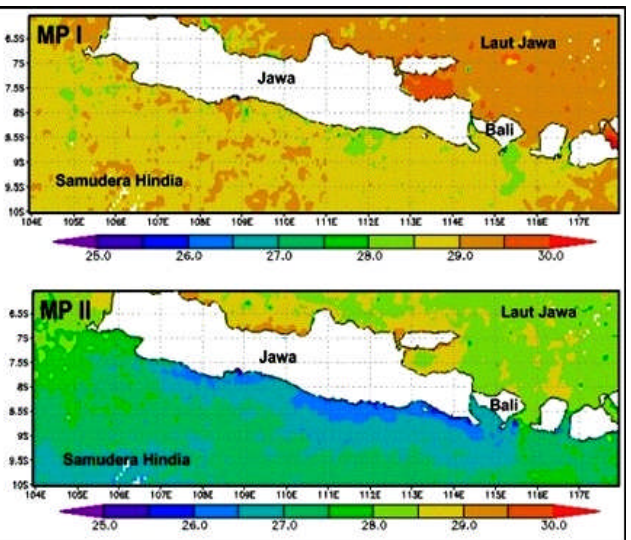

Gambar 6. Sebaran SPL musiman di perairan selatan Jawa-Nusa Tenggara, 2013.

Figure 6. Seasonal distribution of SST in Indian Ocean south off Java-Nusa Tenggara in 2013. 


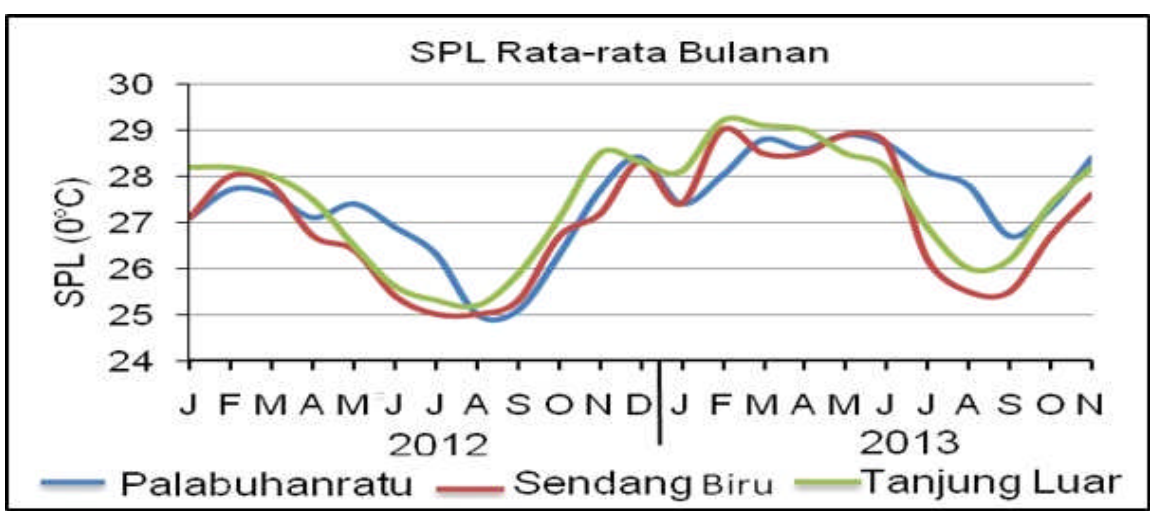

Gambar 7. Fluktuasi SPL rata-rata bulanan di perairan Samudera Hindia selatan Jawa-Nusa Tenggara 2012- 2013.

Figure 7. Monthly fluctuation of SST in estern Indian Ocean south off Java-Nusa Tenggara waters in 2012-2013.

Berdasarkan musim, kisaran nilai sebaran (minimummaksimum) dan nilai rata-rata SPL di lokasi pengamatan sepanjang 2013 bervariasi. Umumnya nilai sebaran ratarata SPL di selatan Jawa pada MP II lebih rendah dibandingkan MT. Nilai sebaran rata-rata SPL pada MT dan MP II di Sendang Biru lebih rendah dibandingkan dengan di perairan Tanjung Luar dan Palabuharatu (Tabel 4).

Tabel 4. Nilai kisaran dan rerata SPL berdasarkan musim pengamatan di lokasi penelitian perairan selatan JawaNusa Tenggara 2013

Table 4. Range value of SST distribution based on monsoon in Indian Ocean south off Java- Nusa Tenggara waters in 2013

\begin{tabular}{lcccccc}
\hline & \multicolumn{6}{c}{ Suhu Perairan $\left({ }^{\circ} \mathbf{C}\right) /$ water temperature $\left({ }^{\circ} \mathbf{C}\right)$} \\
\cline { 2 - 7 } Musim/Monsoon & \multicolumn{2}{c}{ Palabuhanratu } & \multicolumn{2}{c}{ Sendang Biru } & \multicolumn{2}{c}{ Tanjung Luar } \\
\cline { 2 - 7 } & Kisaran/ & Rata-rata/ & Kisaran/ & Rata-rata/ & Kisaran/ & Rata-rata/ \\
& Range & Average & Range & Average & Range & Average \\
\hline MP I & $25,5-29,7$ & 28,77 & $26,9-29,5$ & 28,63 & $27,9-29,7$ & 28,87 \\
MT & $25,4-28,4$ & 27,85 & $24,7-29,3$ & 26,80 & $25,5-28,6$ & 27,27 \\
MP II & $24,7-28,9$ & 27,47 & $24,5-28,3$ & 26,60 & $25,7-29,5$ & 27,03 \\
MB & $27,3-29,3$ & 28,20 & $26,7-27,6$ & 27,80 & $27,4-28,2$ & 27,86 \\
\hline
\end{tabular}

\section{Musim Penangkapan}

Indeks Musim Penangkapan (IMP) menunjukkan musim penangkapan tongkol komo di selatan Jawa dimulai pada Juli sampai November (Gambar 8). Puncak musim terjadi pada Agustus bertepatan dengan puncak MT dan Oktober (MP II). Adapun musim paceklik berlangsung pada MB dengan puncaknya Januari.

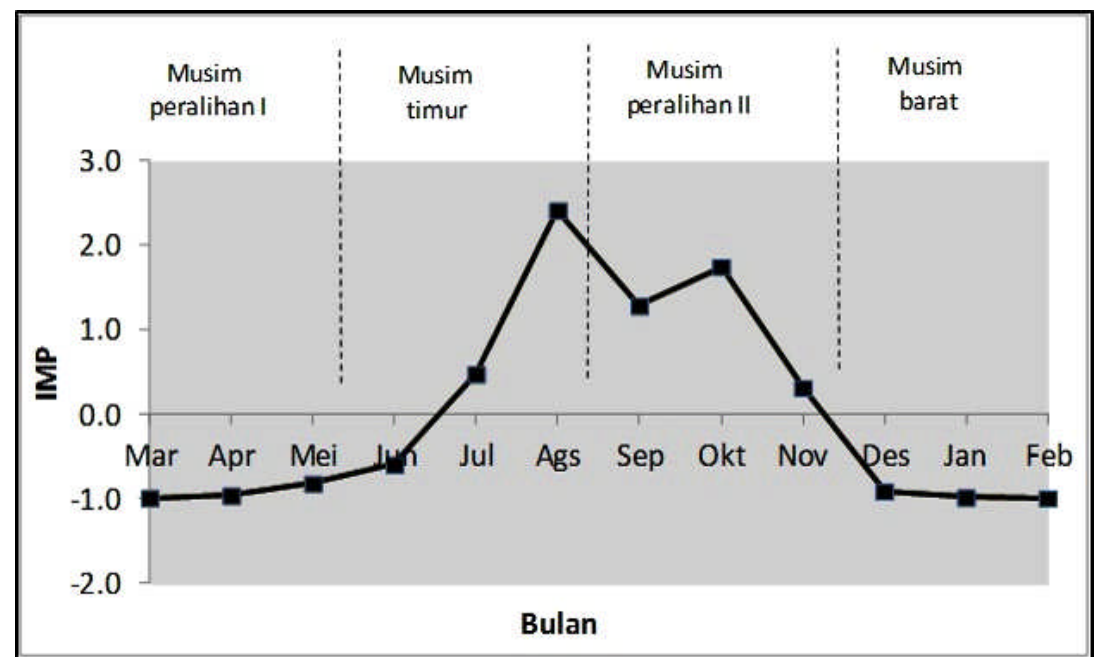

Gambar 8. IMP tongkol komo di perairan Samudera Hindia selatan Jawa-Nusa Tenggara, 2013.

Figure 8. Fishing season index of kawakawa in Indian Ocean south off Java-Nusa Tenggara waters in 2013. 


\section{Bahasan \\ Dinamika SPL dan Musim Penangkapan}

Menurunnya nilai sebaran SPL pada MT disebabkan intrusi massa air dari sub tropis yang mempunyai suhu lebih rendah, posisinya bergeser ke utara bersamaan dengan bertiupnya angin muson tenggara (Purba et al., 1997). Nilai sebaran SPL di perairan selatan Jawa semakin rendah pada Juli-September seiring masuknya MT (muson tenggara). Pada saat itu, di perairan ini terjadi upwelling musiman, respon dari bertiupnya angin muson, berlangsung dari Juni hingga pertengahan Oktober (Susanto et al., 2001). Kejadian upwelling yang memicu turunnya nilai sebaran SPL tersebut, polanya mengalami pergeseran dari arah timur ke barat, sejalan dengan pergerakan angin muson (Amri et al., 2013-b). Nilai sebaran SPL yang jauh lebih rendah pada MT tahun 2012, terkait fenomena El Nino dengan intensitas lemah yang terjadi pada tahun tersebut (Amri et al., 2013-b), memicu upwelling dengan intensitas lebih tinggi dari normalnya.

Dampak upwelling di perairan selatan Jawa, selain penurunan SPL juga meningkatkan produktivitas primer tinggi (Susanto et al., 2001; Amri et al., 2013-b). Hal ini berpengaruh terhadap peningkatan hasil tangkapan ikan per upaya (Setyadji et al., 2017). Tingginya penangkapan ikan tongkol pada MT, diduga terkait dengan kelimpahan sumberdaya ikan pada saat itu, disamping kondisi lingkungan perairan memungkinkan untuk melakukan penangkapan (frekuensi melaut tinggi). Musim paceklik pada MB (Januari) bersamaan dengan berakhirnya dampak upwelling, sehingga ketersediaan pakan berkurang dan kondisi cuaca yang bergelombang besar menyulitkan nelayan melaut.

\section{Dugaan Pemijahan}

Tingginya prosentase tongkol komo yang matang gonad pada Juni (betina 55\% dan jantan 40\%), bertepatan masuknya MT, didukung tingginya produktivitas primer di perairan ini akibat upwelling. Fase matang gonad berlanjut sampai MP II (Oktober) dengan ditemukannya ikan betina spent/TKG V sekitar $11 \%$ dan matang gonad $33 \%$, sementara ikan jantan matang gonad 14\% (TKG IV) dan 29\% (TKG III). Dalam penelitian ini ditemukan juga ikan matang gonad (TKG III) pada Maret. Jika diasumsikan perlu waktu 1-2 bulan untuk mencapai matang gonad (TKG IV), pemijahan ikan tongkol komo di perairan selatan Jawa berlangsung dari Mei-Oktober. Ini identik dengan analisa
IKG yang menunjukkan pemijahan berlangsung pada Mei dan September (Gambar 3).

Sebagai pembanding, di perairan Selat Sunda, tongkol komo matang gonad umumnya terjadi pada Juni $(12,50 \%)$ dan Agustus (16,86\%), sehingga diindikasikan pemijahannya pada bulan tersebut (Ardelia et al., 2016). Pola yang sama juga ditemukan di Laut Jawa (Hidayat et al., 2016). Sementara di perairan India, musim pemijahan tongkol komo berlangsung pada Maret-Juni dan puncaknya April-Mei (Rohit et al., 2012.); dan di Laut Cina Selatan terjadi Juni-Agustus (Williamson, 1970). Berarti, musim pemijahan tongkol komo di perairan selatan Jawa berlangsung lebih lama, yaitu dari Mei-Oktober. Hal ini sejalan dengan yang dinyatakan Collete \& Nauen (1983) dalam Simbolon (2011) bahwa musim pemijahan tongkol bervariasi secara spasial, di perairan Indonesia puncaknya pada Agustus dan Oktober.

\section{Fekunditas dan Diameter Telur dengan SPL}

Tabel 5 memperlihatkan hubungan secara grafis nilai fekunditas dan ukuran diameter telur tongkol komo dengan SPL. Indikator pemijahan ditandai dengan fekunditas tinggi dan dominannya ditemukan telur dengan diamater pada selang kelas berukuran besar, terjadi pada MT dan MP II. Jika dikaitkan dengan nilai sebaran SPL, di perairan Palabuhanratu fekunditas rata-rata tinggi yaitu 652.628 butir (MT) dan 435.985 butir (MP II) dengan telur dominan pada selang kelas diameter berukuran besar 0,48-0,57 mm dan suhu perairan saat itu rendah berkisar $25,4-29,3{ }^{\circ} \mathrm{C}$ atau rata-rata $27,8^{\circ} \mathrm{C}(\mathrm{MT})$ dan berkisar $24,7-28,9^{\circ} \mathrm{C}$ atau rata-rata $27,5^{\circ} \mathrm{C}$ (MP II). Sementara di perairan Tanjung Luar, fekunditas rata-rata mencapai 711.994 butir (MP II) jauh lebih tinggi dibandingkan dengan di Palabuhanratu dengan nilai sebaran suhu berkisar $25,7-29,5^{\circ} \mathrm{C}$ atau ratarata $27,03{ }^{\circ} \mathrm{C}$ (MP II) dan telur dominan pada ukuran selang kelas 0,38-0,47 mm. Jika dibandingkan dengan pada MP I, fekunditas rata-rata di perairan yang sama hanya sekitar 219.167 butir dan suhu perairan lebih hangat yaitu berkisar $27,9-29,5^{\circ} \mathrm{C}$ atau rata-rata $28,9^{\circ} \mathrm{C}$.

Massa air di Palabuhanratu dengan nilai sebaran SPL minimum yaitu $25,4{ }^{\circ} \mathrm{C}$ (MT) dan $24,7{ }^{\circ} \mathrm{C}$ (MP II) serta di Tanjung Luar $25,7{ }^{\circ} \mathrm{C}$ (MP II) merupakan massa air upwelling. Amri et al., 2013-b, menyebutkan massa air upwelling di perairan selatan Jawa didentifikasi sebagai massa air dengan SPL di bawah $26{ }^{\circ} \mathrm{C}$ dan hanya ditemukan musim timur sampai MP II kemudian secara perlahan menghilang pada saat memasuki MB. 
Tabel 5. Hubungan nilai fekunditas dan diameter telur tongkol komo dengan SPL di perairan selatan Jawa pada 2013 Table 5. Correlation between fecundity and egg diameter of kawakawa with SST in estern Indian Ocean south of Java-Nusa Tenggara waters in 2013

\begin{tabular}{|c|c|c|c|c|c|}
\hline \multirow{3}{*}{$\begin{array}{c}\text { Lokasi/ } \\
\text { Location }\end{array}$} & \multirow{2}{*}{\multicolumn{2}{|c|}{$\begin{array}{l}\text { Parameter/ } \\
\text { Parameters }\end{array}$}} & \multicolumn{3}{|c|}{ Monsun/ Monsoon } \\
\hline & & & MP I & MT & MP II \\
\hline & Fekunditas & Kisaran & - & $175.200-833.067$ & $105.400-707.700$ \\
\hline & (butir): & Rerata & - & 652.628 & 435.985 \\
\hline & Diameter telur & Kisaran ukuran & - & $0,08-0,77$ & $0,08-0,77$ \\
\hline & $(\mathrm{mm}):$ & Selang kls & - & & \\
\hline & & dominan & & $0,48-0,57$ & $0,48-0,57$ \\
\hline & Suhu Perairan & Kisaran & - & $25,4-29,3$ & $24,7-28,9$ \\
\hline & $\left({ }^{0} \mathrm{C}\right):$ & Rata-rata & - & 27.8 & 27,5 \\
\hline \multirow[t]{7}{*}{ Sendang Biru } & Fekunditas & Kisaran (butir) & $28.167-2.183 .467$ & - & - \\
\hline & (butir): & Rerata (butir) & 45.608 & - & - \\
\hline & Diameter telur & Kisaran ukuran & $0,08-0,87$ & - & - \\
\hline & $(\mathrm{mm}):$ & Selang kls & & - & - \\
\hline & & dominan & $0,28-0,37$ & & \\
\hline & Suhu Perairan & Kisaran & $26,9-29,5$ & - & - \\
\hline & $\left({ }^{0} \mathrm{C}\right)$ & Rata-rata & 28,6 & - & - \\
\hline \multirow[t]{7}{*}{ Tanjung Luar } & Fekunditas & Kisaran (butir) & $185.330-253.020$ & - & $110.833-2.389 .667$ \\
\hline & (butir): & Rerata (butir) & 219.167 & - & 711.994 \\
\hline & Diameter telur & Kisaran ukuran & $0,08-0,97$ & - & $0,08-0,97$ \\
\hline & $(\mathrm{mm}):$ & Selang kls & & - & \\
\hline & & dominan & $0,38-0,47$ & & $0,38-0,47$ \\
\hline & Suhu Perairan & Kisaran & $27,9-29,5$ & - & $25,7-29,5$ \\
\hline & $\left({ }^{0} \mathrm{C}\right)$ & Rata-rata & 28,9 & - & 27,0 \\
\hline
\end{tabular}

Catatan/Remarks: pada MB/musim barat tidak tersedia data (No data available on west monsoon)

\section{KESIMPULAN}

Musim pemijahan ikan tongkol komo (Euthynnus affinis) di Samudera Hindia selatan Jawa- Nusa Tenggara berlangsung pada musim timur sampai dengan musim peralihan- II (Mei sampai dengan Oktober), ditandai dengan fekunditas tinggi dan telur dengan selang kelas diameter berukuran besar. Pemijahan terjadi bersamaan dengan fenomena upwelling di selatan Jawa yang diindikasikan dengah nilai sebaran Suhu Permukaan Laut rendah. Puncak musim pemijahan terjadi bersamaan dengan puncak musim penangkapan yaitu pada bulan JuliAgustus. Untuk itu, perlu pengaturan pemanfaatan untuk menjamin keberlanjutan sumber daya ikan tongkol komo yaitu melalui pelarangan penangkapan pada saat tersebut.

\section{PERSANTUNAN}

Bahan paper ini merupakan bagian dari kegiatan Penelitian Aspek Biologi, Tingkat Pemanfaatan dan Optimasi Pemanfaatan Sumberdaya Ikan Pelagis Besar di WPP 572, 573 dan 717 Untuk Mendukung Industrialisasi Perikanan, Balai Riset Perikanan Laut TA 2013. Penulis mengucapkan terima kasih kepada enumerator dan pihakpihak yang membantu dalam kegiatan ini.

\section{DAFTAR PUSTAKA}

Abdussamad, E.M., Rohit, P., Koya, K.P.S., \& Sivadas, M. (2012). Status and potential of neritic tunas exploited from Indian waters. IOTC Second Working Party on Neritic Tunas, Malaysia.

Ali, S.A. (2005). Kondisi sediaan dan keragaman populasi ikan terbang (Hirundichthys oxycephalus Bleeker, 1852) di Laut Flores dan Selat Makassar. Disertasi Program Pascasarjana. Universitas Hasanuddin. Makassar. p. 280.

Amri, K., Chodrijah, U., Noegroho, T., Hidayat, T., Wagiyo, K., Restiangsih, Y.H., \& Merta, G.S. (2013-a). Penelitian aspek biologi, tingkat pemanfaatan dan optimasi pemanfaatan ikan pelagis besar di WPP 572, WPP 573 dan WPP 717 untuk mendukung industrialisasi perikanan. Laporan Akhir, Balai Penelitian Perikanan Laut, Jakarta.

Amri, K., Djisman, M., Jonson, L.G., \& Mulyono, S.B. (2013b). Karakteristik suhu permukaan laut dan kejadian upwelling fase Indian Ocean Dipole Mode Positif di Barat Sumatera dan Selatan Jawa. J. Segara, 13(1), 4963,61 .

Ardelia, V., Vitner, Y., \& Boer, M. (2016). Biologi reproduksi ikan tongkol Euthynnus affinis di perairan Selat Sunda. Jurnal Ilmu dan Teknologi Kelautan Tropis, 8(2), 689700.

Chiou, W.D., Cheng, L.Z., \& Chen, K.W. (2004). Reproduction and food habits of Kawakawa Euthynnus affinis in Taiwan. J. Fish. Soc. Taiwan, 31(1), 23-38. 
Collete, B.B., \& Nauen, C.E. (1983). FAO Special Catalogue. Vol. 2 Scombrids of the World an Annotated and Illustrated Catalogue of Tunas, Mackerels, Bonitos, and Related Species Known to Date. FAO Fisheries Synopsis, 125(2), 33-34.

Effendie, M.I. (2002). Biologi perikanan (p. 128). Yayasan Pustaka Nusatama. Yogyakarta.

Effendie, M.I. (1997). Metoda biologi perikanan (p. 45). Yayasan Dewi Sri. Bogor.

Effendie, M.I., \& Sjafei, D.S. (1976). Potensi reproduksi ikan belanak (Mugil dus-sumieri Valenciennes) di perairan Muara Sungai Cimanuk Indramayu. JPPL, 1 , $55-86$.

FAO. (2013). FishStat plus: Capture Production 19502010. Diakses pada tanggal 21 Maret 2013, [www.fao.org].

Gunarso, W. (1985). Tingkah laku ikan dalam hubungannya dengan alat, metode dan teknik penangkapan (p. 149). Institut Pertanian Bogor. Bogor.

Herrera, M., \& L. Pierre. (2009). Status of IOTC databases for neritic tunas. IOTC-2009-WPDCS- 06. $46 \mathrm{pp}$. The paper presented in the $6^{\text {th }}$ session of the Working Party on Data Collection and Statistics, Victoria-Seychelles, 26-27 November 2009.

Hidayat, T., Febrianti, E., \& Restiangsih, Y.H. (2016). Pola dan musim pemijahan Ikan Tongkol komo (Euthynnus affinis Cantor, 1850) di Laut Jawa. BAWAL. 8(2), 101108.

Holden, M. J., \& Raitt, D.F.S. (1974). Manual of fisheries science (p. 135). Food and Agriculture Organization. Rome. Part 2. Methods of recources investigation and their application.

IOTC-WPNT06. (2016). Report of the 6th Session of the IOTC Working Party on Neritic Tunas. Mahe, Seychelles 21 - 24 June 2016. IOTC-2016-WPNT06R [E],p. 89.

IOTC. (2006). Compilation of information on neritic tuna species in the Indian Ocean. A working paper. IOTC2006-SC-INF11.

Kunarso, K., Hadi, S., \& Ningsih, N.S. (2005). Kajian lokasi upwelling untuk penentuan fishing ground potensial ikan tuna. Ilmu Kelautan: Indonesian Journal of Marine Sciences, 10(2), 61-67.
Laevastu, T., \& M. L. Hayes. (1980). Fisheries oceanography and ecology (p. 119). Fishing News Books Ltd. London.

Laevastu, T., \& Hela, I. (1970). Fisheries oceanography (p. 234). Fishing News (Books) LTD. London.

Motlagh, T.S.A., Hashemi, S.A., \& Kochanian, P. (2010). Population biology and assessment of Kawakawa Euthynnus affinis in Coastal Waters of the Persian Gulf and Sea of Oman (Hormozgan Province). Iranian J. of Fisheries Sciences, 9(2), 315-326.

Muthiah, C. (1985). Maturation and spawning of Euthynnus affinis, Auxis thazard and A. rochei in the Mangalore InshoreArea During 1979 to 1982. In Silas E. G. Ed. Tuna Fisheries of the Exclusive Economic Zone of India: Biology and Stock Assessment. Bull.Cent.Mar.Fish.Res.Inst., Cochin, 36, 71-85.

Nontji, A. (1987). Laut Nusantara. Penerbit Djambatan. Jakarta.

Nybakken, J.W. (1992). Biologi laut: Suatu pendekatan ekologis. Alih Bahasa: E. H. E. Koesoebiono. D. G. Bengen, M. Hutomo, \& S. Sukardjo. Penerbit PT. Gramedia. Jakarta.

Purba, M., Natih, I.N.M., \& Naulita,Y. (1997). Karakteristik dan sirkulasi massa air di perairan Selatan JawaSumbawa, 5 Maret-2April dan 23 Agustus-30 September, 1990. Laporan Penelitian. Fakultas Perikanan IPBBPP Teknologi.

Potier. M. (1988). Pecherie de layang et senneur semi industriels Javanais: Perspective Historique Approche systeme. Ph. D. Thesis. Universite de Montpellier. p.280.

Rao, K.V.N. (1964). An account of the ripe ovaries of some Indian tunas. Proc. Symp. Scombroid Fishes, Part 2 Mar.Biol.Assoc. India. 1, 733-43.

Rohit P., Chellappan, A., Abdusssamad, E. M., Joshi, K. K., SaidKoya, K. P., Sivadas,M., Ghosh, S...\& Beni, N. (2012). Fishery and Bionomics of the Little Tuna, Euthynnus affinis (Cantor, 1849) Exploited From IndianWaters. Indian J. Fish., 59(3), 33-42.

Setyadji, B., \& Amri, K. (2017). Pengaruh anomali iklim (ENSO dan IOD) terhadap sebaran ikan pedang (Xiphias gladius) di Samudera Hindia Bagian Timur. Jurnal Segara, 13 (1), 49-63. 
Simbolon, D. (2011). Buku bioekologi dinamika daerah penangkapan ikan (p. 221). Departemen Pemanfaatan Sumberdaya Perikanan, Fakultas Perikanan dan Ilmu Kelautan, Institut Pertanian Bogor. Bogor.

Spiegel, M. R., (1961). Theory and problems of statistics (p. 359). Schaum Publ. Co., New York.

Susanto, R. D., Gordon, A. L., \& Zheng. Q. (2001). Upwelling along the coast of Java and Sumatra and its relation to ENSO, Geoph. Res. Let., 28 (8), 1599-1602.
Williamson, G.R. (1970). Little tuna Euthynnus affinis in the Hong Kong area. Bull.Jap.Soc.Sci.Fish. (36), 918 .

Wyrtki, K. (1962). Physical Oceaography of South East Asia Waters. Naga Report. Vol 2. Scripps Institution of Oceanography La Jolla California. The University of California.

Website: http://gdata1.sci.gsfc.nasa.gov 
Lampiran 1. Prosentase jumlah sampel telur berdasarkan ukuran diameter dan musim di perairan Samudera Hindia selatan Jawa pada 2013

Appendix 1. Percentage of egg sample based on diameter and season size estern Indian Ocean south of Java waters in 2013

\begin{tabular}{|c|c|c|c|c|c|c|c|}
\hline \multirow{4}{*}{ Musim/Monsoon } & \multirow{4}{*}{$\begin{array}{c}\text { Kisaran Diameter } \\
\text { /Diameter range }(\mathbf{m m})\end{array}$} & \multicolumn{6}{|c|}{ Jumlah Telur/Amount of eggs } \\
\hline & & \multicolumn{2}{|c|}{ Palabuhanratu } & \multicolumn{2}{|c|}{ Sendang Biru } & \multicolumn{2}{|c|}{ Tanjung Luar } \\
\hline & & $\mathrm{Jml} / A m$ & & $\mathrm{Jml} / \mathrm{Am}$ & & $\mathrm{Jml} / A m$ & \\
\hline & & & $(\%)$ & & $(\%)$ & & $(\%)$ \\
\hline \multirow{10}{*}{$\begin{array}{l}\text { Musim peralihan } \\
\text { I/Inter monsoon I }\end{array}$} & $0,08-0,17$ & - & - & 1 & 0.3 & - & \\
\hline & $0,18-0,27$ & - & - & 75 & 25.0 & 38 & 12.7 \\
\hline & $0,28-0,37$ & - & - & 88 & 29.3 & 81 & 27.0 \\
\hline & $0,38-0,47$ & - & - & 25 & 8.3 & 103 & 34.3 \\
\hline & $0,48-0,57$ & - & - & 61 & 20.3 & 22 & 7.3 \\
\hline & $0,58-0,67$ & - & - & 37 & 12.3 & 12 & 4.0 \\
\hline & $0,68-0,77$ & - & - & 13 & 4.3 & 2 & 0.7 \\
\hline & $0,78-0,87$ & - & - & - & - & 17 & 5.7 \\
\hline & $0,88-0,97$ & - & - & - & - & 26 & 8.7 \\
\hline & Jumlah/Amount & - & - & 300 & 100 & 301 & 100 \\
\hline \multirow{10}{*}{$\begin{array}{l}\text { Musim timur/East } \\
\text { Monsoon }\end{array}$} & $0,08-0,17$ & 4 & 1.3 & - & - & - & - \\
\hline & $0,18-0,27$ & 9 & 3.0 & - & - & - & - \\
\hline & $0,28-0,37$ & 63 & 21.0 & - & - & - & - \\
\hline & $0,38-0,47$ & 85 & 28.3 & - & - & - & - \\
\hline & $0,48-0,57$ & 95 & 31.7 & - & - & - & - \\
\hline & $0,58-0,67$ & 42 & 14.0 & - & - & - & - \\
\hline & $0,68-0,77$ & 2 & 0.7 & - & - & - & - \\
\hline & $0,78-0,87$ & - & - & - & - & - & - \\
\hline & $0,88-0,97$ & - & - & - & - & - & - \\
\hline & Jumlah/Amount & 300 & 100 & - & - & - & - \\
\hline \multirow{10}{*}{$\begin{array}{l}\text { Musim peralihan } \\
\text { II/Inter monsoon II }\end{array}$} & $0,08-0,17$ & 4 & 1.3 & - & - & - & - \\
\hline & $0,18-0,27$ & 25 & 8.3 & - & - & 5 & 1.7 \\
\hline & $0,28-0,37$ & 61 & 20.3 & - & - & 57 & 19.0 \\
\hline & $0,38-0,47$ & 69 & 23.0 & - & - & 79 & 26.3 \\
\hline & $0,48-0,57$ & 104 & 34.7 & - & - & 42 & 14.0 \\
\hline & $0,58-0,67$ & 36 & 12.0 & - & - & 31 & 10.3 \\
\hline & $0,68-0,77$ & 1 & 0.3 & - & - & 25 & 8.3 \\
\hline & $0,78-0,87$ & - & - & - & - & 47 & 15.7 \\
\hline & $0,88-0,97$ & - & - & - & - & 13 & 4.3 \\
\hline & Total/Total & 300 & 100 & - & - & 299 & 100 \\
\hline
\end{tabular}

